Jurnal Basicedu Volume 4 Nomor 2 April 2020 Hal. 513-521

JURNAL BASICEDU

Research \& Learning in Elementary Education

https://jbasic.org/index.php/basicedu

\title{
PENGARUH PENDEKATAN REALISTIC MATHEMATIC EDUCATION TERHADAP PEMAHAMAN KONSEP DAN DISPOSISI MATEMATIS SISWA SEKOLAH DASAR
}

\author{
Mardiah $^{1}$, Ahmad Fauzan ${ }^{2}$, Yanti Fitria ${ }^{3}$, Hendra Syarifuddin ${ }^{4}$, Farida $^{5}{ }^{5}$, dan Desyandri ${ }^{6}$ \\ Universitas Negeri Padang, Sumatera Barat, Indonesia ${ }^{1,2,3,4,5,6}$ \\ Email: mardiah.syahrel@gmail.com ${ }^{1}$, ahmad.zan66@ gmail.com² ${ }^{2}$,yanti fitria@ fip.unp.ac.id ${ }^{3}$, \\ hendrasy@yahoo.com ${ }^{4}$, faridafahrudin6@gmail.com ${ }^{5}$, desyandri@fip.unp.ac.id ${ }^{6}$
}

\begin{abstract}
Abstrak
Penelitian ini dilatarbelakangi oleh pembelajaran didominasi oleh guru, sehingga siswa cenderung pasif dan kegiatan menjadi kurang bermakna serta kurang bervariasi. Siswa hanya menerima materi pelajaran dari guru, serta menyelesaikan soal-soal yang diberikan guru. Salah satu upaya yang dapat dilakukan untuk mengatasi permasalahan tersebut adalah dengan menggunakan pembelajaran melalui pendekatan RME. Penelitian ini bertujuan untuk mengetahui pengaruh pendekatan RME terhadap pemahaman konsep dan disposisi matematis siswa berdasarkan kemampuan awal pada siswa kelas IV Sekolah Dasar. Data penelitian diperoleh dari hasil tes kemampuan awal dan tes akhir berupa soal pemahanan konsep matematis serta angket disposisi matematis. Berdasarkan hasil analisis data uji anova dua arah dan pembahasan yang dilakukan, diperoleh bahwa pemahaman konsep matematika siswa yang memiliki kemampuan awal tinggi berbeda secara signifikan dengan pemahaman konsep matematika siswa yang memiliki kemampuan awal rendah. Pemahaman konsep matematika siswa yang mengikuti pembelajaran dengan pendekatan RME berbeda secara signifikan dengan pemahaman konsep matematika siswa yang mengikuti pembelajaran konvensional. Tidak terdapat interaksi antara pendekatan RME dan kemampuan awal dalam mempengaruhi pemahaman konsep matematis siswa. Disposisi matematis siswa yang memiliki kemampuan awal tinggi berbeda secara signifikan dengan disposisi matematis siswa yang memiliki kemampuan awal rendah. Disposisi matematis siswa yang mengikuti pembelajaran dengan pendekatan RME berbeda secara signifikan dengan disposisi matematis siswa yang mengikuti pembelajaran konvensional. Selain itu, tidak terdapat interaksi antara pendekatan pembelajaran dan kemampuan awal dalam mempengaruhi disposisi matematis siswa.
\end{abstract}

Kata Kunci: RME, Pemahaman Konsep, Disposisi Matematis, Kemampuan Awal

\begin{abstract}
The aim of this research was to learning that is approved by the teacher, so students must participate and activities become less varied. Students only receive subject matter from the teacher, and solve the questions given by the teacher. One effort that can be done to overcome these problems is to use learning through the RME approach. This study aims to determine the effect of the RME approach to students' understanding of concepts and mathematical dispositions based on initial abilities in grade IV elementary school students. The research data were obtained from the results of the initial ability test and the final test in the form of a mathematical concept holding and mathematical disposition questionnaire. Based on the results of the two-way ANOVA test data analysis and the discussion conducted, it was found that the understanding of mathematical concepts of students who have high initial abilities differ significantly from the understanding of mathematical concepts of students who have low initial abilities. Understanding of mathematical concepts of students who take learning with the RME approach is significantly different from understanding mathematical concepts of students who take conventional learning. There is no interaction between the RME approach and initial ability to influence students' understanding of mathematical concepts. The mathematical disposition of students who have high initial ability differs significantly from the mathematical disposition of students who have low initial ability. The mathematical disposition of students who take learning with the RME approach is significantly different from the mathematical disposition of students who take conventional learning. In addition, there is no interaction between learning approaches and initial abilities in influencing students' mathematical dispositions.
\end{abstract}

Keywords: RME, Concept Understanding, Mathematical Disposition, Early Skills

@ Jurnal Basicedu Prodi PGSD FIP UPTT 2020

$\triangle$ Corresponding author :

Address :-

Email :-

ISSN 2580-3735 (Media Cetak)

Phone ISSN 2580-1147 (Media Online) 
514 Pengaruh pendekatan RME terhadap pemahaman konsep dan disposisi matematis siswa sekolah dasar - Mardiah, Ahmad Fauzan, Yanti Fitria, Hendra Syarifuddin, Farida F, Desyandri

\section{PENDAHULUAN}

Pemahaman konsep matematis merupakan kemampuan yang seharus dimiliki oleh siswa dalam pembelajaran matematika. Pemahaman konsep tidak berarti siswa hafal konsep yang diberikan akan tetapi mampu menggunakannya dalam menyelesaikan masalah yang diberikan. Muliyardi (2002)menyatakan bahwa kemampuan matematis yang pertama adalah kemampuan pemahaman konsep. Zenti, (2016) juga mengemukakan bahwa dalam mempelajari matematika kemampuan yang harus dikuasai siswa adalah pemahaman konsep. Pada pemahaman konsep siswa tidak hanya dilatih hafal suatu fakta atau bagaimana suatu soal harus diselesaikan, tetapi juga paham mengapa soal itu diselesaikan dengan cara tertentu.

Pemahaman konsep matematis penting untuk belajar matematika secara bermakna. Hal tersebut sejalan dengan yang dikemukakan Hudoyo (1988) bahwa "pembelajaran matematika itu memerlukan pemahaman terhadap konsepkonsep dan teorema". Nuraini (2016) juga mengemukakan pentingnya pemahaman konsep agar siswa tahu dan paham sehingga dapat menerapkan konsep dari materi pembelajaran pada soal atau kasus lain.

Disposisi matematis juga hendaknya dimiliki oleh peserta didik dalam pembelajaran matematika karena merupakan salah satu faktor yang ikut menentukan keberhasilan belajar siswa. Siswa memerlukan disposisi yang akan menjadikan mereka gigih menghadapi masalah yang lebih menantang, bertanggung jawab terhadap belajar mereka sendiri, dan mengembangkan kebiasaan baik dalam matematika. Disposisi matematis akan terlihat dari sikap siswa yang mempunyai rasa percaya diri, ketekunan dan memiliki motivasi yang tinggi dalam mempelajari matematika. Hal tersebut sejalan dengan Ningsih, Noer, \& Bharata (2015) yang mendefinisikan bahwa disposisi matematis yaitu rasa percaya diri siswa terhadap kemampuan yang dimilikinya, keinginan yang kuat, rasa ingin tahu, berpikir untuk mengeksplorasi berbagai alternatif penyelesaian masalah, tekun dan kesungguhan dalam belajar matematika.

Selain itu, disposisi matematis juga memiliki peran penting dalam tercapainya tujuan pembelajaran matematika. Salah satu faktor yang menyebabkan rendahnya prestasi belajar matematika adalah rendahnya kemampuan disposisi matematis siswa. Sejalan dengan itu Rahayu (2017) menyatakan bahwa disposisi matematis merupakan ranah afektif yang berperan penting dalam pembelajaran matematika. Disposisi matematis akan tumbuh dalam pembelajaran matematika dan dapat dipergunakan dalam memecahkan masalah dalam kehidupan sehari hari siswa.

Kenyataan menunjukkan bahwa pembelajaran yang dilakukan guru selama ini kurang mendukung berkembangnya pemahaman konsep dan disposisi matematis siswa. Pemahaman konsep yang tidak mantap mengakibatkan penguasaan materi matematika yang juga rendah. Hal ini terlihat pada rendahnya nilai matematika Indonesia di tingkat internasional. Hasil survey Program for Internasional Student Assessment (PISA) 2015 yang menunjukkan Indonesia baru bisa menduduki peringkat 69 dari 76 negara. Hasil ini menjelaskan siswa lemah dalam geometri, khususnya dalam pemahaman ruang dan bentuk. Penelitian ini menerangkan bahwa kemampuan pemahaman konsep siswa masih rendah. Studi TIMSS (Trend in International Mathematics and Science Study), yang menerangkan siswa Indonesia berada di peringkat ke-38 dari 42 negara. Penelitian ini menjelaskan bahwa pembelajaran matematika di Indonesia lebih banyak pada penguasaan keterampilan dasar, 
515 Pengaruh pendekatan RME terhadap pemahaman konsep dan disposisi matematis siswa sekolah dasar - Mardiah, Ahmad Fauzan, Yanti Fitria, Hendra Syarifuddin, Farida F, Desyandri

hanya sedikit sekali penekanan pemahaman konsep matematika dalam konteks sehari-hari.

Penelitian Tim Pusat Pengembangan Penataran Guru Matematika juga mengungkapkan bahwa di beberapa wilayah Indonesia, sebagian besar siswa kesulitan dalam menyelesaikan soalsoal pemecahan masalah dan menerjemahkan soal kehidupan sehari-hari ke dalam model matematika (Fadjar, 2009). Hasil penelitian ini menjelaskan bahwa kemampuan pemahaman konsep siswa juga masih rendah. Rendahnya pemahaman konsep matematika juga terlihat melalui rata-rata hasil Ujian Nasional kelas VI pada tingkat Sekolah Dasar di Kota Payakumbuh tahun pelajaran 2016/2017 yaitu 66,20. Hal tersebut dimungkinkan karena pemahaman konsep matematis siswa masih rendah.

Bukti lain dari masalah pemahaman konsep adalah banyaknya siswa yang belum betul menjawab soal yang diberikan. Salah satu soal dan jawaban siswa kelas IV SD Negeri 46 Payakumbuh pada semester ganjil tentang soal pemahaman konsep yaitu tentang penjumlahan pecahan. Berdasarkan jawaban siswa, terlihat siswa masih belum bisa menyelesaikan soal dengan benar. Sebagian siswa menjawab soal pecahan dengan kesalahan yang serupa.Terlihat siswa mengerjakan soal penjumlahan pecahan dengan menjumlahkan pembilang dijumlahkan dengan pembilang dan penyebut dijumlahkan dengan penyebut, tanpa menyamakan terlebih dahulu penyebutnya. Hal ini membuktikan siswa tersebut tidak paham dengan konsep penjumlahan pecahan.

Berdasarkan hasil observasi dan wawancara yang penulis lakukan dengan beberapa guru SD di Gugus III Kecamatan Payakumbuh Barat pada semester ganjil, yaitu pada bulan September 2017. Sebagian besar guru mengatakan bahwa dalam belajar matematika terlihat banyak siswa yang kurang percaya diri dalam mengerjakan soal matematika, memecahkan masalah, memberi alasan dan menyampaikan gagasan, keingintahuan dan daya temu siswa dalam melakukan tugas matematika masih rendah. Penulis sebagai guru SD juga merasakan bahwa siswa kurang tekun dalam mengerjakan tugas, kurang bersemangat, kebanyakan siswa kurang menyenangi pelajaran matematika dan lebih suka mencontoh tugas temannya.

Dalam penelitiannya, Syaban

menemukan bahwa daya dan disposisi matematis siswa belum tercapai sepenuhnya. Hal tersebut antara lain karena pembelajaran cenderung teacher centered yang menekankan pada proses prosedural, tugas latihan yang mekanistik, dan kurang memberikan peluang kepada siswa untuk mengembangkan kemapuan matematisnya.

Disposisi matematis siswa yang rendah menyebabkan nilai matematika siswa juga rendah tergambar di SD Negeri se Gugus III Kecamatan Payakumbuh Barat, Kota Payakumbuh. Hasil ujian semester genap matematika siswa menunjukkan hasil yang kurang memuaskan jika dibandingkan dengan nilai Kriteria Ketuntasan Minimal (KKM) yang diterapkan di sekolah yaitu 75 . Rendahnya hasil belajar siswa tersebut diduga karena pemahaman konsep dan disposisi matematis siswa yang masih rendah.

Kemampuan awal merupakan kemampuan yang dapat menjadi dasar untuk menerima pengetahuan baru. Kemampuan awal merupakan pondasi dan dasar untuk pembentukan konsep baru dalam pembelajaran matematika. Kemampuan awal siswa sebenarnya telah dipunyai oleh siswa sebelum ia mengikuti pembelajaran yang akan diberikan. Menurut Gerlach dan Ely (Rusman, 2010), " kemampuan awal siswa ditentukan dengan memberikan tes awal". Dari kemampuan awal tersebut dapat diketahui apakah siswa tersebut telah mempunyai pengetahuan yang merupakan prasyarat untuk mengikuti 
516 Pengaruh pendekatan RME terhadap pemahaman konsep dan disposisi matematis siswa sekolah dasar - Mardiah, Ahmad Fauzan, Yanti Fitria, Hendra Syarifuddin, Farida F, Desyandri

pembelajaran. Kemampuan awal siswa tersebut juga dimaksudkan agar siswa dapat memahami materi matematika secara mendalam dan bermakna. Suatu proses pembelajaran dikatakan bermakna jika seseorang sudah dapat mengaitkan konsep-konsep yang ada dengan baik. Hal ini sesuai dengan yang di nyatakan Ausubel (Slavin, 2011), "Belajar bermakna merupakan suatu proses dikaitkannya informasi yang baru pada konsepkonsep yang relevan yang terdapat dalam struktur kognitif seseorang”.

Pengetahuan yang sudah dimiliki siswa akan sangat menentukan bermakna atau tidaknya suatu proses pembelajaran. Itulah sebabnya para guru harus mengecek, memperbaiki dan menyempurnakan pengetahuan para siswa sebelum membahas materi baru. Maksud dari pernyataan di atas adalah kemampuan awal matematika merupakan salah satu faktor yang menentukan sukses atau tidaknya siswa belajar matematika di tingkat sekolah dasar.

Dari permasalahan di atas, maka perlu dicarikan solusi untuk mengatasinya sehingga pembelajaran matematika mampu mengembangkan pemahaman konsep dan disposisi matematis siswa. Salah satu usaha yang dapat dilakukan dalam proses belajar khususnya peningkatan pemahaman konsep dan disposisi matematis siswa adalah penggunaan pendekatan Realistic Mathematics Education (RME).

Heuvel-Panhuizen (Fauzan, 2002) mengatakan bahwa RME merupakan suatu pembelajaran yang menggunakan masalah kontekstual dan situasi kehidupan nyata untuk memperoleh dan mengaplikasikan konsep matematika. Masalah kontekstual yang diberikan mampu mendorong siswa untuk menemukan hubungan suatu materi yang dipelahri dengan situasi dunia nyata(Desyandri, Yesya, \& Alwi, 2018). Selanjutnya Freudenthal (Gravemeijer, 1994) merumuskan lima karakteristik RME yaitu penggunaan masalah kontekstual, penggunaan model, konstribusi siswa, interaktif, dan penjalinan/penguatan. Dickinson, P. (Wijaya, 2012) menyatakan pendekatan berbasis RME menunjukkan hasil yang berbeda daripada metode solusi lainnya dikarenakan RME menggunakan konteks yang tidak hanya ilustrasi melainkan menggunakan konteks dari dunia nyata. RME menggunakan model dari konteks seperti gambar kemudian direpresentasikan dalam bentuk garis, rasio, tabel dan sebagainya, konteks dalam RME dipilih untuk mengembangkan berbagai strategi yang berbeda dan siswa selalu merefleksikan secara konstan. Peran guru dalam RME lebih dominan pada pemberian motivasi, fasilitator, dan pemberi stimulus agar siswa aktif dalam kegiatan pembelajaran. Fitria \& Idriyeni (2017) mengungkapkan bahwa guru harus mampu mengelola kelas dengan baik dan menciptakan aktivitas pembelajaran yang sesuai dengan pengembangan diri.

Pendekatan RME cocok digunakan untuk mengatasi masalah pemahaman konsep matematika siswa, seperti hasil penelitian Rahayu (2017) menyimpulkan bahwa terdapat pengaruh yang positif pendekatan RME terhadap pemahaman konsep matematika siswa kelas VII Madrasah Tsanawiyah Hasanah Pekanbaru. Sejalan dengan itu, penelitian (Zenti, 2016) juga menyimpulkan bahwa pemahaman konsep matematis siswa dengan menggunakan RME lebih baik daripada pemahaman konsep matematis siswa dengan menggunakan pembelajaran konvensional di kelas VIII MTsN kota Padang.

Pendekatan RME juga dirasa cocok untuk mengatasi masalah disposisi matematis siswa sesuai dengan hasil penelitian dari Ningsih et al (2015) yang menyatakan pembelajaran menggunakan model Realistic Mathematics Education efektif untuk meningkatkan disposisi matematis siswa. Pendekatan ini juga mengaitkan 
517 Pengaruh pendekatan RME terhadap pemahaman konsep dan disposisi matematis siswa sekolah dasar - Mardiah, Ahmad Fauzan, Yanti Fitria, Hendra Syarifuddin, Farida F, Desyandri

kemampuan awal siswa dengan pelajaran selanjutnya, sesuai dengan yang dikemukakan Hadi (2005) bahwa RME bertolak dari masalah kontekstual dan melihat kemampuan awal yang dimiliki siswa.

Berdasarkan hal di atas, maka tujuan penelitian ini adalah melihat pengaruh pendekatan RME terhadap kemampuan pemahaman konsep dan disposisi matematis siswa.

\section{METODE}

Penelitian yang dilaksanakan adalah penelitian quasi eksperimen, yang melibatkan dua kelas yaitu kelas eksperimen dan kelas kontrol Siswa dikelompokkan berdasarkan kemampuan awal. Kemampuan awal siswa dibagi menjadi kemampuan awal tinggi dan rendah. Pendekatan yang digunakan adalah pendekatan Realistic Mathematic Education dan pendekatan konvensional.

Variabel bebas dalam penelitian ini adalah pembelajaran dengan pendekatan Realistic Mathematic Education dan pendekatan konvensional. Variabel terikatnya adalah data pemahaman konsep dan disposisi matematis. Kemampuan awal berperan sebagai variable moderator. Populasi pada penelitian ini adalah seluruh peserta didik kelas IV SD di gugus III Kecamatan Payakumbuh Barat yang terdaftar pada tahun pelajaran 2017/2018. pengambilan sampel dilakukan secara acak atau random sampling untuk memperoleh kelas eksperimen dan kelas control. Instrument yang digunakan pada penelitian ini adalah instrument tes dan instrument non tes Instrument tes berupa soal-soal dengan pendekatan Realistic Mathematic Education. Instrument non tes yang berupa angket disposisi matematis. Kedua instrument sebelum digunakan dilakukan uji coba dan validasi sehingga diperoleh instrument yang valid dan reliable.

\section{HASIL DAN PEMBAHASAN}

Hasil penelitian ini dilihat pada pengujian hipotesis melalui hasil pengolahan data anaova 2 arah seperti tabel di bawah ini.

Tabel 1. Anava 2 arah

\begin{tabular}{|l|c|c|c|c|}
\hline $\begin{array}{c}\text { Sumber } \\
\text { Variansi }\end{array}$ & $\begin{array}{c}\text { Jumlah } \\
\text { Kuadrat }\end{array}$ & $\begin{array}{c}\text { Derajat } \\
\text { Kebebasan }\end{array}$ & $\begin{array}{c}\text { Rataan } \\
\text { Kuadrat }\end{array}$ & Hitung \\
\hline Metode & $9.707,85$ & 1 & $9.707,85$ & $\begin{array}{c}9.707,85 \\
\begin{array}{c}112,33 \\
=86,4\end{array}\end{array}$ \\
\hline $\begin{array}{l}\text { Kemamp } \\
\text { uan awal }\end{array}$ & $17.005,5$ & 1 & $\begin{array}{c}17.005,5 \\
1\end{array}$ & 151,39 \\
\hline Interaksi & 240,59 & 1 & 240,59 & 2,142 \\
\hline Galat & $5.953,56$ & 53 & 112,33 & \\
\hline Jumlah & $32.907,5$ & 56 & & \\
\hline
\end{tabular}

F tabel $:(1,53)=4,02$

Keputusan:

\section{Hipotesis pertama}

F hitung 151,39 lebih besar dari F tabel 4,02 berarti H0 ditolak. Dapat disimpulkan pemahaman konsep matematika siswa yang memiliki kemampuan awal tinggi berbeda secara signifikan dengan pemahaman konsep matematika siswa yang memiliki kemampuan awal rendah.

\section{Hipotesis kedua}

F hitung kedua 86,4 lebih besar dari Ftabel 4,02 berarti H0 ditolak. Dapat disimpulkan pemahaman konsep matematis siswa yang mengikuti pembelajaran dengan pendekatan RME berbeda secara signifakan dengan pemahaman konsep matematika siswa yang mengikuti pembelajaran dengan pendekatan konvensional.

\section{Hipotesis Ketiga}

F hitung 2,142 lebih kecil dari F tabel 4,02 maka H0 diterima. Dapat disimpulkan bahwa tidak terdapat interaksi antara pendekatan pembelajaran dan kemampuan awal siswa dalam mempengaruhi pemahaman konsep matematis siswa. 
518 Pengaruh pendekatan RME terhadap pemahaman konsep dan disposisi matematis siswa sekolah dasar - Mardiah, Ahmad Fauzan, Yanti Fitria, Hendra Syarifuddin, Farida F, Desyandri

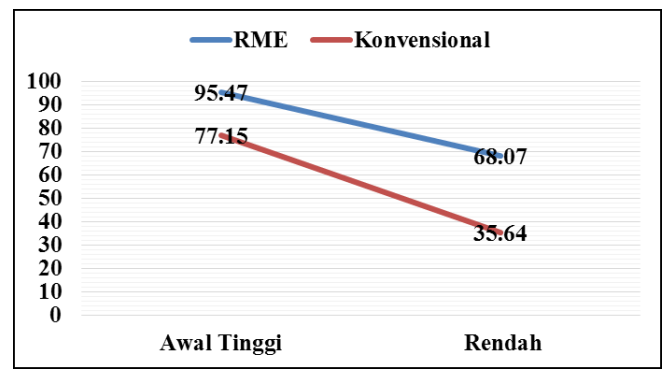

Gambar 1. Diagram Uji Pemahaman Konsep Matematis Siswa

\section{Hipotesis keempat}

F hitung 96,64 lebih besar dari F tabel 4,02 berarti H0 ditolak. Dapat disimpulkan dispoisi matematis siswa yang memiliki kemampuan awal tinggi berbeda secara signifikan dengan disposisi matematis siswa yang memiliki kemampuan awal rendah.

\section{Hipotesis Kelima}

F hitung 82,21 lebih besar dari Ftabel 4,02 berarti H0 ditolak. Dapat disimpulkan disposisi matematis siswa yang mengikuti pembelajaran dengan pendekatan RME berbeda secara signifakan dengan pemahaman disposisi matematis siswa yang mengikuti pembelajaran dengan pendekatan konvensional.

\section{Hipotesis Keenam}

F hitung 1,71 lebih kecil dari $\mathrm{F}$ tabel 4,02 maka H0 diterima. Dapat disimpulkan bahwa tidak terdapat interaksi antara pendekatan pembelajaran dan kemampuan awal siswa dalam mempengaruhi disposisi matematis siswa.

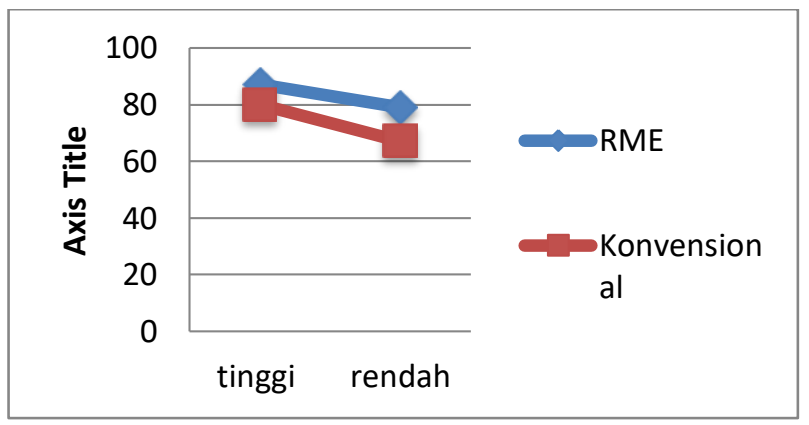

Gambar 2. Diagram Uji Interaksi Disposisi Matematis Siswa
Hasil pengujian hipotesis pertama dan keempat menunjukkan bahwa Fhitung> Ftabel, dengan H0 ditolak dan $\mathrm{H} 1$ diterima. Hal ini berarti bahwa secara umum pemahaman konsep matematis dan disposisi matematis siswa berkemampuan awal tinggi berbeda dengan siswa yang berkemampuan awal rendah. Hal ini menunjukkan bahwa kemampuan awal matematika menjadi salah satu faktor yang menentukan sukses atau gagalnya siswa belajar matematika di tingkat sekolah.

Materi yang dipelajari dalam matematika saling terkait satu-sama lain. Suherman (2003) menyatakan bahwa topik atau konsep prasyarat sebagai dasar untuk memahami topik atau konsep selanjutnya. Dalam pembelajaran RME, Gravemeije (Fauzan, 2002) menjelaskan bahwa RME memiliki prinsip pemodelan (emergin models), yakni siswa menyelesaikan suatu persoalan matematika terlebih dahulu menggunakan model informal. Dalam hal ini, model informal berkaitan dengan kemampuan awal yang dimiliki siswa. Selain itu, Teffers (Wijaya, 2012) menyatakan bawah salah satu karakteristik RME adalah keterkaitan. Artinya, RME mengintegrasikan unit-unit matematika.

Penggunaan pendekatan RME memiliki pengaruh terhadap kemampuan awal siswa. Pada pengekatan RME terdapat karakteristik interaktif. Teffers (Wijaya, 2012) mengungkapkan bahwa interaksi antara siswa dengan guru merupakan hal yang mendasar dalam RME. Dalam hal ini, siswa yang berkemampuan awal rendah dapat meningkatkan pemahaman konsep matematis dan disposisi matematisnya melalui kegiatan pembelajaran RME. Kemudian Hadi (2005) menyatakan bahwa konsepsi guru terhadap pembelajaran RME, yaitu guru sebagai fasilitator belajar, guru membangun pengajaran yang interaktif, dan guru memberikan kesempatan 
519 Pengaruh pendekatan RME terhadap pemahaman konsep dan disposisi matematis siswa sekolah dasar - Mardiah, Ahmad Fauzan, Yanti Fitria, Hendra Syarifuddin, Farida F, Desyandri

kepada siswa untuk secara aktif menyumbang pada proses belajar dirinya.

Hasil pengujian hipotesis kedua dan kelima dapat dilihat bahwa Fhitung> Ftabel, dengan $\mathrm{H} 0$ ditolak dan $\mathrm{H} 1$ diterima. Hal ini berarti bawah pemahaman konsep dan disposisi matematis siswa pada kelas eksperimen yang menggunakan pembelajaran melalui pendekatan RME lebih tinggi dibandingkan kelas kontrol yang menggunakan pembelajaran konvensional. Titik awal dalam pembelajaran RME ialah menggunakan konteks nyata dunia nyata. Teffers (Wijaya, 2012) mengungkapkan bahwa penggunaan konteks membuat siswa dilibatkan secara aktif untuk melakukan kegiatan eksplorasi permasalahan serta juga bermanfaat untuk meningkatkan motivasi dan keterkaitan siswa dalam belajar matematika. Hal ini tentunya berpengaruh pada pemahaman konsep matematis dan disposisi matematis siswa.

Pembelajaran RME menghasilkan pembelajaran yang bermakna. Siswa diberi kesempatan untuk mengalami proses yang sama dengan proses yang dilalui oleh para pakar matematika ketika menemukan konsep-konsep matematika. Dalam hal ini, siswa melakukan aitivitas belajar dengan guide reinvention Gravemeijer (Fauzan, 2002) menyatakan bahwa kegiaan belajar dilakukan dengan memberikan soal-soal kontekstual yang mempunyai berbagai kemungkinan solusi (soal divergen), dilanjutkan dengan mematematisasi prosedur pemecahan yang sama; serta perancangan rute (alur) belajar sedemikian rupa sehingga siswa menemukan sendiri konsep-konsep atau hasil.

Pembelajaran yang bermakna berkaitan dengan pemahaman siswa terhadap konsep-konsep matematika yang telah dipelajari atau yang ditemukannya. Hal ini sesuai dengan pernyataan Hudoyo (1988:153) bahwa pembelajaran matematika itu memerlukan pemahaman terhadap konsep-konsep. Konsep-konsep itu akan melahirkan teorema dan rumus, kemudian diaplikasikan ke situasi yang lain, maka perlu adanya keterampilan menggunakan konsep-konsep dan teorema tersebut. Oleh karena itu pembelajaran matematika berkisar tentang bagaimana konsep, teorema dan keterampilan.

Pendekatan RME dengan pembelajaran yang berkaitan konteks dunia nyata siswa menumbuhkan disposisi matematis siswa. Disposisi matematis menjadi salah satu faktor yang ikut menentukan keberhasilan belajar siswa, tentunya juga terhadap pemahaman konsep matematis siswa. NCTM (2000) menyatakan bahwa sikap siswa dalam menghadapi matematika dan keyakinannya dapat mempengaruhi prestasi mereka dalam matematika. Kilpatrick, Swafford, dan Findell (Syaban, 2009) menamakan disposisi matematis sebagai productive disposition (disposisi produktif), yakni pandangan terhadap matematika sebagai sesuatu yang logis, dan mengahasilkan sesuatu yang berguna.

Hasil analisis pengujian hipotesis yang ketiga menunukkan bahwa Fhitung $<$ Ftabel, dengan $\mathrm{H} 0$ diterima dan $\mathrm{H} 1$ ditolak. Hal ini berarti bahwa tidak terdapat interaksi antara pendekatan pembelajaran dan kemampuan awal siswa dalam mempengaruhi pemahaman konsep matematis siswa. Siswa yang mengikuti pembelajaran melalui pendekatan RME dengan siswa mengikuti pembelajaran konvensional tidak mempunyai beda yang signifikan secara perhitungan statistika antara kemampuan awal tinggi dan rendah.

Kemampuan awal sangat berpengaruh terhadap hasil belajar. Hal ini dikarenakan materi yang dipelajari dalam matematika saling terkait satu-sama lain. Hal ini sesuai dengan pernyataan Suherman (2003) bahwa dalam matematika terdapat topik atau konsep prasyarat sebagai dasar 
520 Pengaruh pendekatan RME terhadap pemahaman konsep dan disposisi matematis siswa sekolah dasar - Mardiah, Ahmad Fauzan, Yanti Fitria, Hendra Syarifuddin, Farida F, Desyandri

untuk memahami topik atau konsep selanjutnya. Dalam hal ini, kemampuan awal yang dimiliki siswa tidak bergantung pada metode pembelajaran atau sebaliknya dalam mempengaruhi pemahaman konsep matematis siswa. Siswa yang memiliki kemampuan awal tinggi cenderung memiliki pemahaman konsep matematis tinggi, dan sebaliknya.

Hasil analisis pengujian hipotesis yang keenam dapat disimpulkan bahwa tidak terdapat interaksi antara pendekatan pembelajaran dan kemampuan awal siswa dalam mempengaruhi disposisi matematis siswa. Artinya siswa yang mengikuti pembelajaran melalui pendekatan RME dengan siswa mengikuti pembelajaran konvensional tidak mempunyai beda yang signifikan secara perhitungan statistika antara kemampuan awal tinggi dan rendah. Hal ini menunjukkan bahwa faktor kemampuan awal tidak tergantung pada metode pembelajaran atau sebaliknya dalam mempengaruhi disposisi matematis siswa. Sumarmo (2002)mendefenisikan bahwa disposisi matematis (mathematical disposition) yaitu keinginan, kesadaran, kecenderungan dan dedikasi yang kuat pada diri siswa untuk berpikir dan berbuat secara matematik dengan cara yang positif. Dalam prestasi anak mengembangkan orientasi tak berdaya dimana bila mereka memandang prilakunya sebagai kegagalan, mereka akan sering merasa cemas yang akan berakibat pada timbulnya rasa rendah diri. Sebaliknya bila anak memiliki orientasi kemampuan maka anak akan lebih peduli pada strategi belajar mereka.

\section{SIMPULAN}

Dari hasil penelitian dan hasil analisis data yang telah dilakukan maka dapat ditarik kesimpulan: pemahaman konsep matematika dan disposisi matematis siswa yang memiliki kemampuan awal tinggi berbeda secara signifikan dengan pemahaman konsep dan disposisi matematika siswa yang memiliki kemampuan awal rendah. Pemahaman konsep dan disposisi matematis siswa yang mengikuti pembelajaran dengan pendekatan RME berbeda secara signifikan dengan pemahaman konsep dan disposisi matematis siswa yang mengikuti pembelajaran konvensional. Selain itu, tidak terdapat interaksi antara pendekatan RME dan kemampuan awal dalam mempengaruhi pemahaman konsep dan disposisi matematis siswa.

\section{DAFTAR PUSTAKA}

Desyandri, Yesya, D. P., \& Alwi, E. (2018). Pengaruh Penggunaan Model Contextual Teaching and Learning (CTL) dalam Pembelajaran PKn di Sekolah Dasar. EJournal Inovasi Pembelajaran SD, 6(1), 110 .

Fadjar, S. (2009). Kemahiran Matematika. Yogyakarta: Departemen Pendidikan Nasional.

Fauzan, A. (2002). Applying Realistic Mathematics Education (RME) in Teaching Geometri in Indonesia Primary Schools. Enschede: Print Partners Ipskamp.

Fitria, Y., \& Idriyeni. (2017). Development of Problem-based Teaching Materials for the Fifth Graders of Primary School. Jurnal Ta'dib, 20(2), 99-106.

Gravemeijer. (1994). Developing Realistics Mathematics Education. Freudenthal Institute Utrecht.

Hadi, S. (2005). Pendidikan Matematikan Realistik dan Implementasinya. Banjarmasin: Tulip Banjarmasin.

Hudoyo, H. (1988). Mengajar Belajar Matematika. Jakarta: Dekdikbud.

Muliyardi. (2002). Strategi Pembelajaran Matematika. Padang: FMIPA UNP.

NCTM. (2000). Principles and Standar for scholl Mathematics.

Ningsih, S. U., Noer, S. H., \& Bharata, H. (2015). Efektivitas Model Realistic Mathematics Education terhadap Kemampuan Representasi dan Disposisi Matematis Siswa. Jurnal Pendidikan Matematika, 3(5).

Nuraini, S. (2016). Pengaruh Pendekatan Realistic Mathematics Education (RME) Terhadap 
521 Pengaruh pendekatan RME terhadap pemahaman konsep dan disposisi matematis siswa sekolah dasar - Mardiah, Ahmad Fauzan, Yanti Fitria, Hendra Syarifuddin, Farida F, Desyandri

Kemampuan Pemahaman Matematis dan

Kepercayaan Diri Siswa pada Materi

Menyederhanakan Pecahan. Jurnal Pena

Ilmiah, l(1).

Rahayu, R. (2017). Pembelajaran Matematika

Realistik Indonesia Berbasis Keunggulan

Lokal untuk Membangun Disposisi

Matematis dan Karakter Cinta Tanah Air. In

Seminar Nasional Aktualisasi Kurikulum

2013 di Sekolah Dasar melalui

GerakanLiterasi Sekolah untuk Menyiapkan Generasi Unggul dan Berbudi Pekerti (pp. 152-163).

Rusman. (2010). Model-model Pembelajaran. Jakarta: Rajawali Pers.

Slavin, R. E. (2011). Psikologi Pendidikan Teori dan Praktik. Jakarta: PT Indeks.

Suherman, E. (2003). Strategi Pembelajaran Matematika Kontemporer. Bandung: FMIPA UPI.

Sumarmo, U. (2002). Daya dan Disposisi Matematik: Apa, Mengapa dan Bagaimana Dikembangkan pada Siswa Sekolah Dasar dan Menengah. In Seminar Matematika. Jurusan Matematika ITB.

Syaban, M. (2009). Menumbuh Kembangkan Daya dan Disposisi Matematis Siswa Sekolah Menengah Atas Melalui Pembelajaran Investigasi. Jurnal Formatif, 3(2).

Wijaya, A. (2012). Pendidikan Matematika Realistik; Suatu Alternatif Pendekatan Pembelajaran Matematika. Yogyakarta: Graha Ilmu.

Zenti, M. (2016). Efektivitas Pembelajaran Matematika dengan Pendekatan Matematika Realistik (PMR) Ditinjau dari Pemahaman Konsep Matematis Siswa Kelas VIII MTsN 5 Padang. Jurnal Pendidikan. 